\title{
The effect of protein and essential amino acid supplementation on muscle strength and performance in patients with chronic heart failure: a systematic review
}

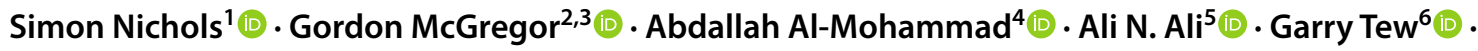 \\ Alasdair F. O'Doherty ${ }^{6}$ (i)
}

Received: 18 April 2019 / Accepted: 4 October 2019 / Published online: 28 October 2019

(c) The Author(s) 2019

\begin{abstract}
Purpose Critically low skeletal muscle mass and strength, observed in $20 \%$ of people with chronic heart failure (CHF), reduces functional capacity, quality of life (QoL) and survival. Protein and essential amino acid (EAA) supplementation could be a viable treatment strategy to prevent declines in muscle strength and performance, and subsequently improve QoL and survival. This systematic review (PROSPERO: CRD42018103649) aimed to assess the effect of dietary protein and/or EAA supplementation on muscle strength and performance in people with CHF.

Methods Searches of PubMed, MEDLINE and Embase identified studies that reported changes in strength or muscle performance following protein and/or EAA supplementation in patients with CHF. Following PRISMA guidelines and using predefined inclusion/exclusion criteria relating to participants, intervention, control, outcome and study design, two reviewers independently screened titles, abstracts and full manuscripts for eligibility. Risk of bias was assessed using Cochrane Risk of Bias Tool (RCTs) or Mixed Methods Appraisal Tool (cohort studies). Data were extracted for analysis using predefined criteria.

Results Five randomised controlled trials (RCT) and one cohort study met our inclusion criteria. All RCTs had a high risk of bias. The methodological quality of the cohort study was moderate. Heterogeneity of extracted data prevented metaanalyses, qualitative synthesis was therefore performed. Data from 167 patients with CHF suggest that protein and/or EAA supplementation does not improve strength, but may increase six-minute walk test distance, muscle mass and QoL. Conclusions The limited quality of the studies makes firm conclusions difficult, however protein and/or EAA supplementation may improve important outcome measures related to sarcopenia. High-quality randomised controlled studies are needed.
\end{abstract}

Keywords Heart failure $\cdot$ Sarcopenia $\cdot$ Cachexia $\cdot$ Frailty $\cdot$ Muscles $\cdot$ Amino acids $\cdot$ Diet

Electronic supplementary material The online version of this article (https://doi.org/10.1007/s00394-019-02108-z) contains supplementary material, which is available to authorized users.

Simon Nichols

s.j.nichols@shu.ac.uk

1 Centre for Sports and Exercise Science, Sheffield Hallam University, Collegiate Campus, Sheffield S10 2BP, UK

2 Centre for Exercise and Health, Department of Cardiopulmonary Rehabilitation, University Hospitals Coventry and Warwickshire NHS Trust, Coventry, UK

3 School of Health and Life Sciences, Coventry University, Coventry, UK
4 Sheffield Teaching Hospitals NHS Foundation Trust, Herries Rd, Sheffield, UK

5 Sheffield National Institute for Health Research Biomedical Research Centre, Glossop Road, Sheffield, UK

6 Department of Sport, Exercise and Rehabilitation, Northumbria University, Newcastle-Upon-Tyne, UK 
Table 1 PICOS criteria for included studies

\begin{tabular}{ll}
\hline PICOS & Criteria \\
\hline Participants & Heart failure patients with preserved ejection fraction \\
& Heart failure patients with reduced ejection fraction \\
Intervention & Dietary protein supplementation for at least 4 weeks \\
& Dietary essential amino acid supplementation for at least 4 weeks \\
Control & Standard medical care (no change in diet) \\
& Modification of a control patient's diet resulting in a lower pro- \\
& tein intake, compared to intervention patients \\
Outcomes & Muscle strength \\
& Muscle performance \\
Study type & Randomised controlled trial \\
& Cohort study
\end{tabular}

\section{Introduction}

Chronic heart failure (CHF) affects $11.8 \%$ of people over the age of 60 years [1] and is a leading cause of death and disability [2]. Structural and functional cardiac abnormalities, leading to imbalances between metabolic supply and demand, are the defining physiological characteristics of CHF [3]. A key phenotype of CHF is reduced cardiac output $(Q)$ and arterial compliance, which collectively inhibit haemodynamic perfusion of skeletal muscle during physical activity [3]. Such impaired cardiovascular function may contribute to exercise intolerance; however, $\mathrm{CHF}$ also causes profound adverse changes to skeletal muscle physiology, which plays a significant role in mediating physical disability [3].

Changes in skeletal muscle physiology occur in CHF patients who have either reduced (HFrEF) or preserved (HFpEF) left ventricular ejection fraction (LVEF) [4-8]. These changes have been described in detail elsewhere $[4,9]$ and include a decrease in the number of type I muscle fibres, a decrease in the oxidative capacity and cross-sectional area of type II muscle fibres, a reduction in mitochondrial volume within muscle fibres, a reduction in enzymes required for aerobic metabolism and an increase in glycolytic enzymes. Reduced skeletal muscle aerobic enzyme activity, mitochondrial density and perfusion matching with oxidative muscle fibres contribute to poor aerobic fitness, faster depletion of phosphocreatine and an earlier reliance on glycolytic pathways during exercise [4]. Patients with CHF are also more likely to suffer from muscle atrophy and reduced strength, a condition termed sarcopenia [10-12]. In CHF, sarcopenia is associated with an increased risk of premature mortality [13], a reduction in six-minute walk test (6MWT) distance and physical function, low aerobic fitness, and poor healthrelated quality of life (HRQoL) $[11,14]$. Treatments that are capable of reversing or preventing the development of sarcopenia in patients who have CHF are therefore needed.
Insufficient dietary protein intake is a strong predictor of developing sarcopenia in patients with heart disease [15]. Regular dietary supplementation with protein or essential amino acids (EAA) has been shown to augment skeletal muscle strength and mass in healthy adults [16], and in patients with a long-term condition; defined by the authors as, "including coronary artery disease, chronic heart failure, type 2 diabetes mellitus, chronic obstructive pulmonary disease, osteoporosis, the metabolic syndrome and dementia" [17]. This is most likely due to the capacity of dietary protein and/or EAA supplementation to stimulate the mammalian target of rapamycin (mTOR) pathway and muscle anabolism [18-20]. Protein and/or EAA supplementation may therefore help to improve strength and muscle performance in patients with CHF, however this has not been widely investigated.

The primary aim of this systematic review was to assess the effects of dietary protein and/or EAA supplementation on skeletal muscle strength and performance in people with CHF. The secondary aims were to explore the effect of this intervention on body composition, HRQoL, aerobic fitness and safety. Intervention adherence and adverse events were also reported.

\section{Methods}

This review adhered to the Preferred Reporting Items for Systematic Reviews and Meta-Analyses (PRISMA) guidelines. A PRISMA checklist is available from Online Resource 1 [21]. A priori aims, eligibility criteria and methods were registered with PROSPERO (CRD42018103649).

\section{Study selection criteria}

The Participants, Intervention, Control, Outcomes and Study Type (PICOS) criteria are outlined in Table 1. Randomised controlled trials (RCT) and cohort studies were included if the intervention involved protein or EAA supplementation 
for at least 4 weeks. Protein supplementation was defined as a request for the participant to consume protein and/or EAA in addition to their habitual dietary intake. We conservatively chose to include studies that had a supplementation period of at least 4 weeks because a recent systematic review that investigated protein supplementation in patients with a long-term condition, suggested that interventions as short as 6 weeks may improve muscle strength and mass [17]. Further inclusion criteria were: studies that recruited (1) male or female patients, (2) patients who were $>18$ years, and (3) patients with a diagnosis of HFrEF or HFpEF. Studies were also required to have a primary outcome of skeletal muscle strength or performance. Examples of performance outcome measures included walking tests, the short physical performance battery (SPPB) or gait speed, because these have been recommended in international sarcopenia guidelines [10]. Acceptable comparator groups included patients that were assigned to standard care (no change to diet) or the modification of a patient's diet that resulted in a lower protein intake in comparison with the intervention group.

Studies were excluded if: (1) research was conducted in animal models, (2) participants were $<18$ years of age, (3) there was no dietary protein or EAA supplementation, (4) the supplementation period was less than 4 weeks or (5) data were from case reports. Systematic reviews were also excluded. Language of publication was not an exclusion criterion.

\section{Search strategy}

A search of PubMed, MEDLINE, and Embase, was conducted from the dates of inception (1879, 1879 and 1947, respectively), to August 2018. Search terms, including medical subject headings (MeSH) were developed by SN and AOD. These were refined by an independent research librarian who performed the literature search. The search strategy combined keywords describing the primary condition [heart failure (MeSH) OR cardiac failure OR left ventricular failure] AND secondary condition [sarcopenia (MeSH) OR cachexia (MeSH) OR lean muscle OR muscle mass]. The strategy also included terms describing the 'intervention' [protein and amino acids (MeSH)]. There are numerous methods of assessing strength and muscle performance. To reduce the risk of excluding relevant articles, we did not restrict the outcome measures using specific search terms. A full search strategy is provided in Online Resource 2. The reference lists of manuscripts that met our inclusion criteria were also screened for articles that met our inclusion criteria (see below).

\section{Study selection}

After the search was completed, duplicate articles were removed. SN and AOD independently screened titles and abstracts in accordance with inclusion and exclusion criteria. Full-text manuscripts of the abstracts that met our inclusion criteria were assessed against inclusion and exclusion criteria. Differences between the author's lists of included studies were resolved through discussion between SN, AOD and ANA, at both stages of the review process. Data extraction was performed by $\mathrm{SN}$ using a preestablished pro forma. AOD reviewed the extracted data against the original manuscripts.

\section{Data extraction and analysis}

The following data were extracted: muscle strength, muscle performance, body composition, aerobic fitness, HRQoL, age, sex and number of participants, LVEF, primary diagnosis (HFrEF or HFpEF), and description of the supplementation regime (type of supplement, dose, frequency and duration), attrition, adherence, and safety (adverse events, renal function). Transparent reporting of adverse events provides important context about the benefit and risk profile of an intervention and should be an outcome reported in clinical trials [22]. Serious adverse events were defined as any event or reaction that resulted in death, life-threatening illness, hospital admission or prolongation of existing hospitalisation, persistent or significant disability or incapacity [23]. Adverse events were defined as an untoward medical event that occurred during activities required for the study [23], irrespective of whether they were thought to be related to the intervention. Changes in renal function were also reported to explore the safety of protein and/or EAA supplementation in patients with CHF. Diets that are high in protein may be associated with a decline in renal function in patients with heart disease [24]. Where outcome measures were assessed at multiple time points, testing conducted closest to cessation of supplementation was included for analysis. Attempts were made to contact corresponding authors when missing data were identified.

We planned to conduct meta-analysis on quantitative data extracted from included studies. Outcomes of interest were extracted as inter-group mean difference, with standard deviation $( \pm)$, or median with inter-quartile range (IQR), according to how they were reported in the original manuscript. Intra-group differences were reported, where inter-group differences were unavailable. Data dispersion reported as standard error of the mean (SEM) were converted to standard deviations using the following equation:

$\mathrm{SD}=\mathrm{SEM} \times \sqrt{n}$ 
Fig. 1 PRISMA flow chart

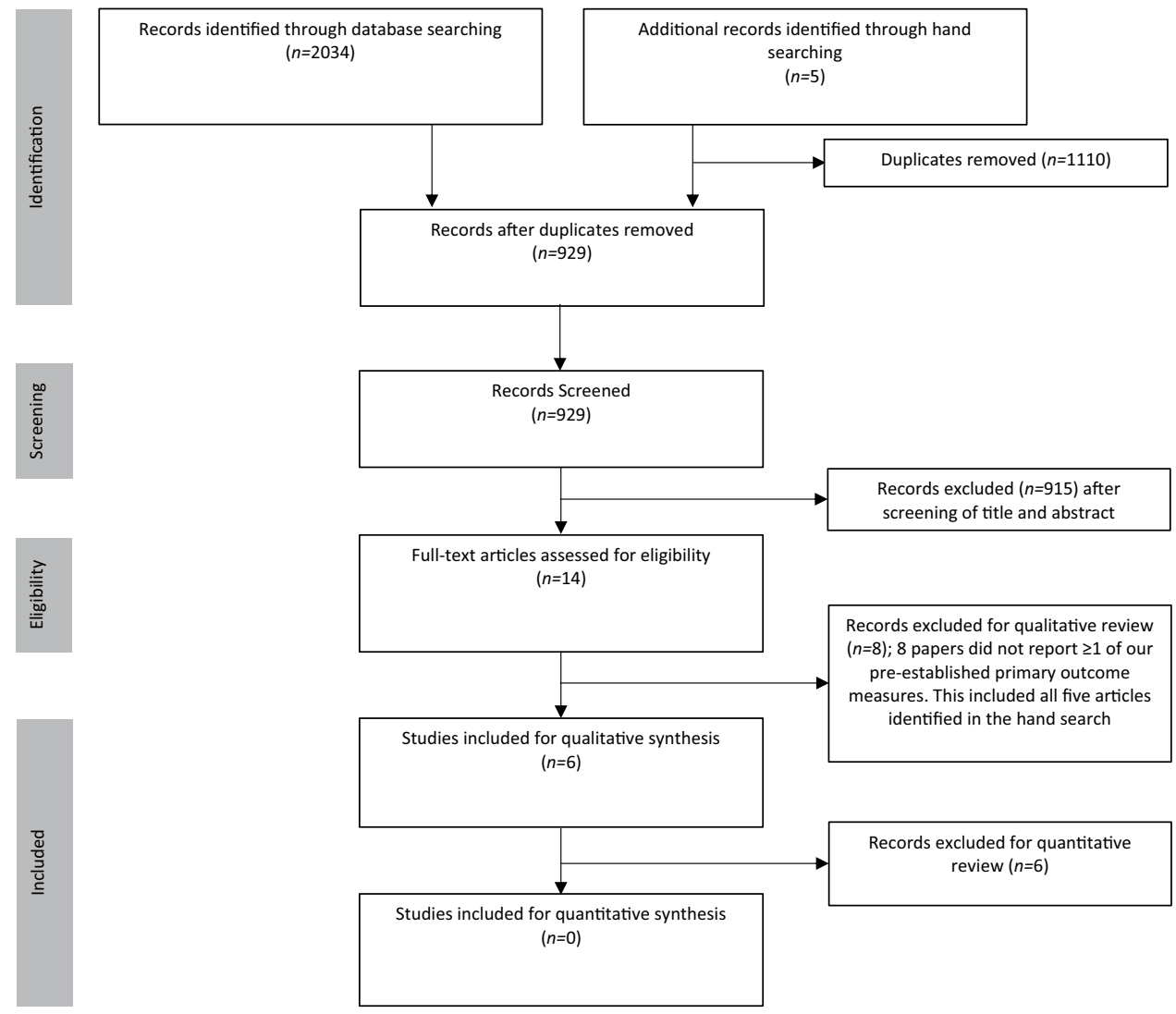

where; SD is the standard deviation, SEM is the standard error of the mean and $n$ is the number of participants in the group of interest. Improvements in an outcome variable were considered statistically significant if it achieved a significance threshold outlined in an a priori sample size calculation. Where sample size calculations were not provided, findings were considered significant if a $P$ value $<0.05$ was reported.

\section{Risk of bias and quality appraisal}

Randomised controlled trials (RCTs) meeting our study inclusion criteria were independently evaluated by $\mathrm{SN}$ and AOD for risk of bias, using the Cochrane Risk of Bias tool [25]. Bias attributed to patient selection, randomisation, blinding, attrition and data reporting was assessed. Studies with a high risk of bias in one or more domains were classified as high risk. Studies that had an unclear risk of bias in one or more domains, but were not considered to have any domains at high risk of bias, were classified as moderate risk. Any study meeting low-risk criteria for all domains was considered to be at low risk of bias. A methodological appraisal of cohort studies was undertaken by SN and ANA using the Mixed Methods Appraisal Tool (MMAT) [26]. Objective quality scoring is not recommended because it assigns unjustified weighting to different elements of trial design and reporting [25]. A subjective assessment was therefore undertaken (Online Resource 3).

\section{Results}

A PRISMA flow diagram is shown in Fig. 1. Searches identified $n=833, n=469$ and $n=732$ articles from Embase, MEDLINE and Pubmed, respectively (total $n=2034$ ). After the removal of duplicate articles $(n=1110)$, database searches identified 924 records. A further five articles were identified through hand searches (total $n=929$ ). Fourteen full-text articles were retrieved after screening of titles and abstracts. Eight articles, including the five studies identified in the hand search, were excluded (Online Resource 4) and six articles were retained for review [27-32]. Data reported within these manuscripts was heterogeneous and there was insufficient data to perform meta-analysis or quantitative synthesis due to the risk of generating misleading findings [33]. Data were therefore qualitatively synthesised. No authors responded to our request for further information.

\section{Study characteristics}

Study characteristics are reported in Table 2. One cohort study [32] and five RCTs [27-31] were identified. 


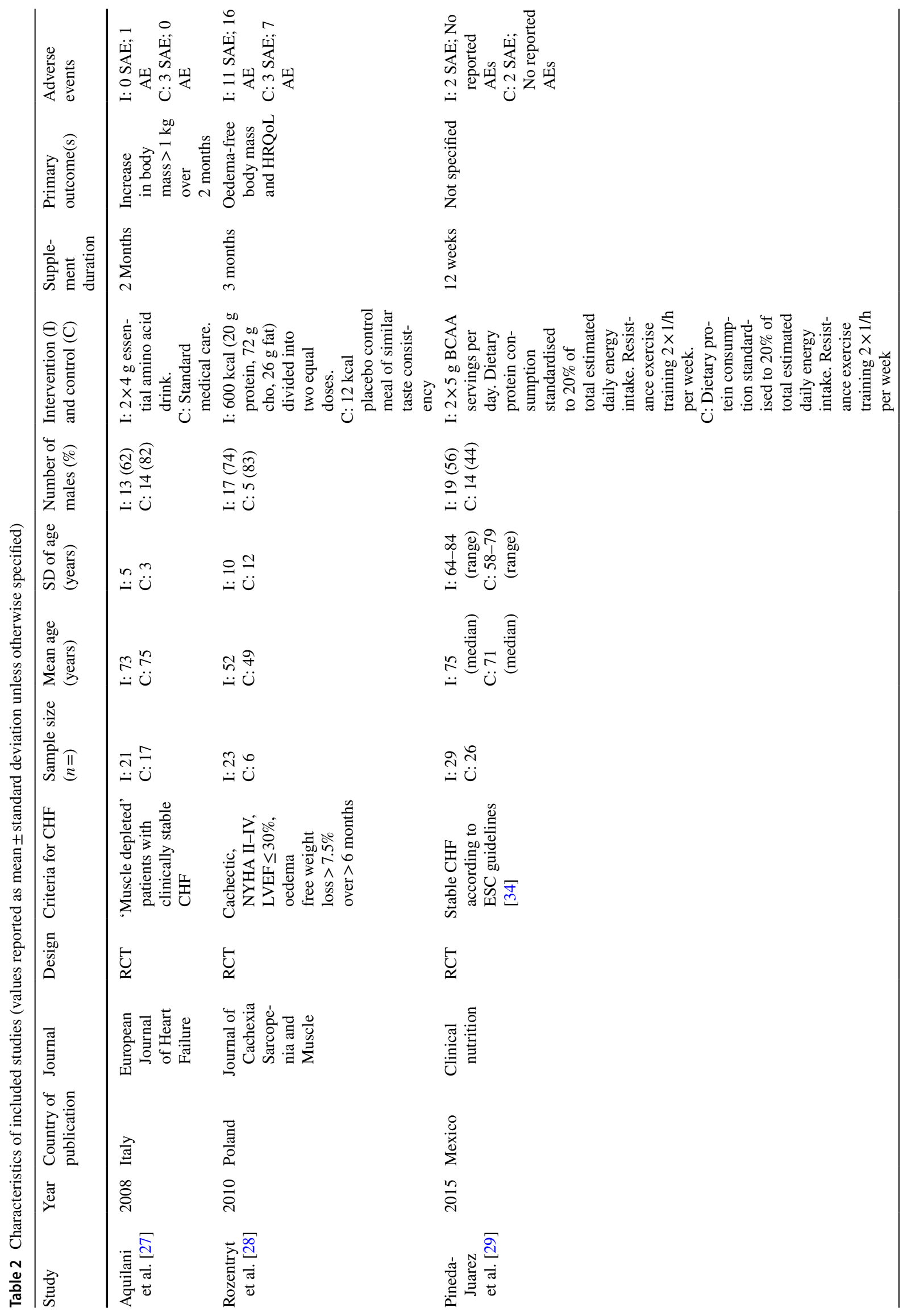




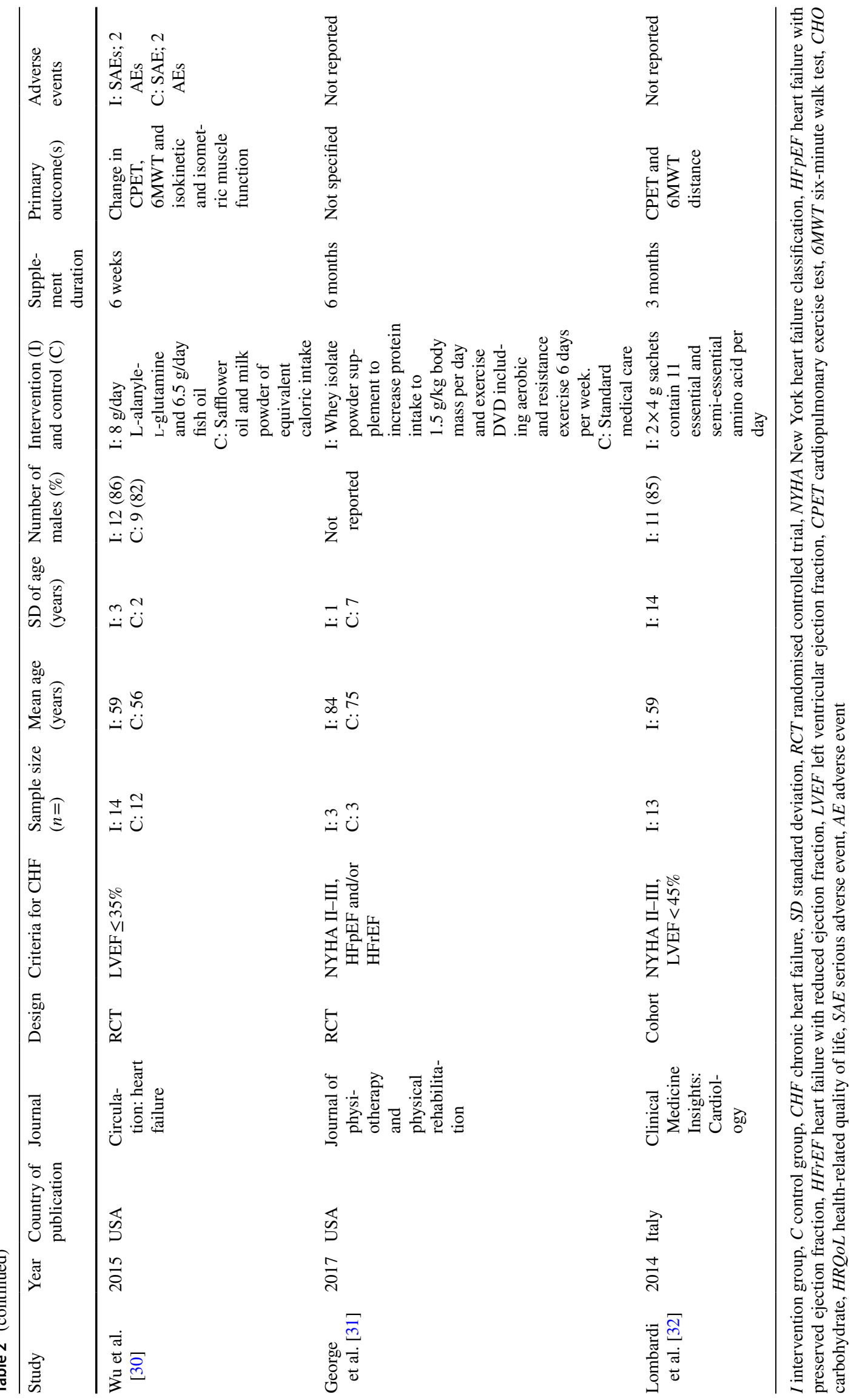


Table 3 Risk of bias table for included studies

\begin{tabular}{|c|c|c|c|c|c|c|c|}
\hline Authors & 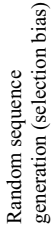 & 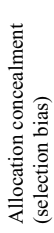 & 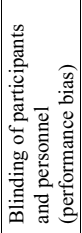 & 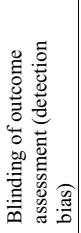 & 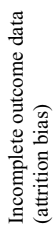 & 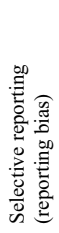 & 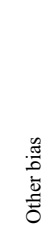 \\
\hline Aquilani et al. (2008) [27] & & & & $?$ & $?$ & $?$ & \\
\hline Rozentryt et al. (2010) [28] & & & & $?$ & & & \\
\hline $\begin{array}{l}\text { Pineda-Juarez et al. (2015) } \\
{[29]}\end{array}$ & & & & & ? & & \\
\hline Wu et al. (2015) [30] & & & & $?$ & + & & \\
\hline George et al. (2017) [31] & & & & 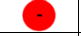 & & & \\
\hline Lomabardi et al. (2014) [32] & $\mathrm{N} / \mathrm{A}$ & N/A & N/A & $\mathrm{N} / \mathrm{A}$ & N/A & N/A & N/A \\
\hline
\end{tabular}

One-hundred and three $(n=103)$ patients were recruited to intervention groups and 64 patients were recruited to control groups, providing a total population of 167 patients from six studies. One RCT did not report primary outcome data for their control group [28].

Patient inclusion criteria were different between studies. Reduced LVEF or New York Heart Failure (NYHA) classification II-IV was most frequently reported as the criteria to define heart failure $[28,30,32]$. Two studies specifically recruited patients with clinical signs of muscle depletion $[27,28]$. Muscle depletion was defined as: $>7.5 \%$ oedemafree weight loss in $\geq 6$ months, excluding patients with signs of acute inflammatory processes, cancer, or severe chronic renal failure (serum creatinine $>250 \mu \mathrm{mol} / \mathrm{L}$ ) [25], or age and sex adjusted arm circumferences in the lowest 10th percentile in accordance with data from Frischano and colleagues [35].

\section{Risk of bias}

All five RCTs had a high risk of bias (Table 3) [27-31]. Randomised controlled trials had between two and six domains that were considered to be at a high risk of bias. The methodological quality of the cohort study was considered moderate due to the length of the recruitment not being reported (Online Resource 3) [32]. Selective data reporting was common across all studies and numerical $P$-values were often unreported. Only one study reported a sample size calculation [30].

\section{Duration of protein and essential amino acid supplementation}

Intervention characteristics (Table 2) were heterogeneous. The duration of dietary supplementation of protein/EAA ranged from 6 weeks [30] to 6 months [31]. Three studies supplemented protein/EAA for 3 months $[28,29,32]$ and one study supplemented protein/EAA for 2 months [27].

\section{Daily protein and essential amino acid dose}

Five out of six studies increased daily dietary protein and/ or EAA intake with supplementation. Among these five studies, two administered dietary protein; one used $1.5 \mathrm{~g} /$ $\mathrm{kg}$ per day of whey protein powder [31] and one used a $300 \mathrm{kcal}$ of twice daily multi-macronutrient supplement containing $20 \mathrm{~g}$ of protein [28]. Three of the five studies administered an EAA supplement without further alteration to the patient's habitual macro, or micro nutrient intake. Two of these provided $4 \mathrm{~g}$ doses, twice daily [27, 32] and one administered an $8 \mathrm{~g}$ dose, once daily [30].

Instead of increasing daily dietary protein and/or EAA intake by the same (relative or absolute) amount, one of the six studies adjusted daily dietary protein intake to meet $20 \%$ of a patient's daily estimated energy intake in both the intervention and the control groups [29]. Ten grams of protein was then removed from the daily diets of patients in the intervention group and replaced with $2 \times 5 \mathrm{~g}$ of a combined EAA and non-EAA supplement [29]. Supplement doses are shown in Table 2.

\section{Combined interventional studies}

One study combined protein supplementation with a home-based aerobic and resistance exercise training intervention [31]. Exercise was delivered via a DVD or pamphlet and aimed to improve ambulation, balance, lifting and functional independence. Each 20-min exercise session was prescribed six times per week (three aerobic and three resistance exercise sessions on alternating days). This exercise training intervention was only prescribed to the supplemented group.

A second study combined EAA supplementation with a twice weekly ( $1 \mathrm{~h}$ per session) resistance exercise training programme [29]. Resistance exercise training consisted of a warmup that included mobility exercises (four sets of six different exercises) and skeletal muscle stretching (four sets of six different exercises). The conditioning phase also involved six different exercises. Each type of resistance exercise was conducted in four sets of 15-20 repetitions. Barbell and exercise bands providing a resistance between 500 and $1500 \mathrm{~g}$ were used. Both the control and the supplement intervention groups undertook this exercise protocol.

One study combined EAA ( $8 \mathrm{~g}$ /day) with $6.5 \mathrm{~g} /$ day of polyunsaturated fatty acid (fish oil) [30]. 
Table 4 Changes in strength measurements $($ mean $\pm \mathrm{SD})$

\begin{tabular}{|c|c|c|c|c|}
\hline Study & Sample size $(n=)$ & Measurement of strength & Mean change in strength (SD) & Significant improvement \\
\hline Pineda-Juarez et al. [29] & $\begin{array}{l}\text { I: } 29 \\
\text { C: } 26\end{array}$ & Handgrip (dominant arm; kg) & $\begin{array}{l}\mathrm{I}:+8.0(-6.8 \text { to } 15.3)^{\mathrm{a}} \\
\mathrm{C}:+11.4(3.6 \text { to } 21.4)^{\mathrm{a}}\end{array}$ & $\begin{array}{l}\text { I: No-P>0.05 } \\
\text { C: No-P }>0.05 \\
\text { Inter-group: Not reported }\end{array}$ \\
\hline \multirow[t]{4}{*}{ Wu et al. [30] } & \multirow[t]{4}{*}{$\begin{array}{l}\text { I: } 14 \\
\text { C: } 12\end{array}$} & $\begin{array}{l}\text { Isometric leg extension-peak torque/ } \\
\text { BW (\%) }\end{array}$ & $\begin{array}{l}\text { I: } 196.0 \pm 37.4 \text { to } 206.0 \pm 41.2 \\
\text { C: } 177.0 \pm 62.4 \text { to } 200.0 \pm 69.3\end{array}$ & $\begin{array}{l}\text { I: No- } P>0.05 \\
\text { C: No- } P>0.05 \\
\text { Inter-group: No- } P>0.05\end{array}$ \\
\hline & & $\begin{array}{l}\text { Isometric leg flexion-peak torque/ } \\
\text { BW }(\%)\end{array}$ & $\begin{array}{l}\text { I: } 90.0 \pm 18.7 \text { to } 90.0 \pm 18.7 \\
\text { C: } 76.0 \pm 20.8 \text { to } 90.0 \pm 27.7\end{array}$ & $\begin{array}{l}\text { I: No- } P>0.05 \\
\text { C: No- } P>0.05 \\
\text { Inter-group: No- } P>0.05\end{array}$ \\
\hline & & $\begin{array}{l}\text { Isokinetic leg extension-peak torque/ } \\
\text { BW (\%) }\end{array}$ & $\begin{array}{l}\text { I: } 153.0 \pm 29.9 \text { to } 160.0 \pm 33.7 \\
\text { C: } 147.0 \pm 58.9 \text { to } 173.0 \pm 69.3\end{array}$ & $\begin{array}{l}\text { I: No- } P>0.05 \\
\text { C: No- } P>0.05 \\
\text { Inter-group: No- } P>0.05\end{array}$ \\
\hline & & $\begin{array}{l}\text { Isokinetic leg flexion-peak torque/ } \\
\text { BW (\%) }\end{array}$ & $\begin{array}{l}\text { I: } 70.0 \pm 18.7 \text { to } 77.0 \pm 15.0 \\
\text { C: } 61.0 \pm 20.8 \text { to } 76.0 \pm 31.2\end{array}$ & $\begin{array}{l}\text { I: No- } P>0.05 \\
\text { C: No- } P>0.05 \\
\text { Inter-group: No- } P>0.05\end{array}$ \\
\hline \multirow[t]{2}{*}{ George et al. [31] } & \multirow[t]{2}{*}{$\begin{array}{l}\text { I: } 3 \\
\text { C: } 3\end{array}$} & Handgrip (right arm; kg) & $\begin{array}{l}\mathrm{I}:+1.8 \pm 1.6 \\
\mathrm{C}:+2.4 \pm 2.1\end{array}$ & $\begin{array}{l}\text { I: No- } P>0.05 \\
\text { C: No- } P>0.05 \\
\text { Inter-group: No- } P>0.05\end{array}$ \\
\hline & & Quadriceps Strength (kg) & $\begin{array}{l}\mathrm{I}:+5.7 \pm 1.0 \\
\mathrm{C}:+10.2 \pm 8.7\end{array}$ & $\begin{array}{l}\text { I: No-P>0.05 } \\
\text { C: No-P }>0.05 \\
\text { Inter-group: No-P>0.05 }\end{array}$ \\
\hline
\end{tabular}

Mean change refers to changes in a measurement that occurred between the baseline assessment, and the assessment that immediately followed supplement cessation

$I$ intervention group, $C$ control group, $B W$ body weight

${ }^{\text {a } I n t e r-q u a r t i l e ~ r a n g e ~}$

\section{Control group characteristics}

Control group designs varied between studies. Two control groups were provided with standard medical care (no placebo) $[27,31]$. One received safflower oil and milk powder of equivalent caloric intake [30]. Another received the same resistance exercise training programme provided to the intervention group, whilst having their dietary protein intake adjusted to $20 \%$ of their estimated daily energy intake [29]. Only one control group was provided with a placebo drink (12 kcal) of 'similar taste and consistency' [28].

\section{Strength measurements}

Three studies with a combined total of $n=46$ intervention patients and $n=41$ control patients investigated changes in skeletal muscle strength [29-31] (Table 4). One of these studies included exercise prescription in the intervention group only [31], one study included exercise prescription in the intervention and control groups [29] and one study did not prescribe exercise [30]. One study reported percentage changes in handgrip strength only [29], one reported changes in handgrip strength (numerical data unavailable) and isokinetic leg dynamometry [30] and one reported both handgrip $(\mathrm{kg})$ and quadriceps $(\mathrm{kg})$ strength, but did not provide information of how measurements were recorded [31]. No studies reported any statistically significant improvements in strength in patients assigned to the intervention, compared to patients in control groups.

\section{Muscle performance measurements}

Five studies assessed changes in muscle performance (6MWT or get up and go test, Table 5) [27, 28, 30-32], however, one of these studies did not quantitatively report intervention or control data [30]. Data on changes in muscle performance were reported in four studies that included $n=74$ intervention and $n=38$ control patients. All four studies measured changes in 6MWT distance [27, 28, 31, 32], one of which also reported changes in timed get up and go [31]. One study did not report control data for the 6MWT $(n=6)$ [28] and one was a cohort study $(n=13)$ [32].

One study, where only the intervention group was prescribed exercise, did not find an increase in 6MWT distance or timed get up and go among intervention patients $(n=3)$, when compared to control patients $(n=3)$ [31]. Three studies [27, 28, 32] including one cohort study [32], reported a significant improvement in 6MWT distance after the nutritional intervention $(n=57)$. Only one study conducted inter-group statistical comparisons of changes in 6MWT distance. 6MWT distance increased significantly 
Table 5 Changes in muscle performance measurements (mean \pm SD)

\begin{tabular}{|c|c|c|c|c|}
\hline Study & Sample size $(n=)$ & Measurement of muscle function & Change in muscle function (SD) & Significant improvement \\
\hline Aquilani et al. [27] & $\begin{array}{l}\mathrm{I}: 21 \\
\mathrm{C}: 17\end{array}$ & $6 \mathrm{MWT}(\mathrm{m})$ & $\begin{array}{l}\text { I: } 331.0 \pm 124.0 \text { to } 405.0 \pm 130.0 \\
\text { C: } 298.0 \pm 142.0 \text { to } 310.0 \pm 155.0\end{array}$ & $\begin{array}{l}\text { I: Yes }-P<0.001 \\
\text { C: No- } P>0.05 \\
\text { Inter-group: Yes }-P=0.02\end{array}$ \\
\hline Rozentryt et al. [28] & $\begin{array}{l}\text { I: } 23 \\
\text { C: } 6\end{array}$ & $6 \mathrm{MWT}(\mathrm{m})$ & $\begin{array}{l}\text { I: } 366.0 \pm 110.0 \text { to } 410.0 \pm 107.0 \\
\text { C: Not Reported }\end{array}$ & $\begin{array}{l}\text { I: Yes }-P=0.020 \\
\text { C: No- }-P>0.05 \\
\text { Inter-group: Not reported }\end{array}$ \\
\hline Wu et al. [30] & $\begin{array}{l}\text { I: } 14 \\
\text { C: } 12\end{array}$ & $6 \mathrm{MWT}(\mathrm{m})$ & $\begin{array}{l}\text { I: Numerical values not reported } \\
\text { C: Numerical values not reported }\end{array}$ & $\begin{array}{l}\text { I: No- } P>0.05 \\
\text { C: No- } P>0.05 \\
\text { Inter-group: No- } P>0.05\end{array}$ \\
\hline \multirow[t]{2}{*}{ George et al. [31] } & $\begin{array}{l}\text { I: } 3 \\
\text { C: } 3\end{array}$ & 6MWT (m) & $\begin{array}{l}\text { I: }-49.0 \pm 42.0 \\
\text { C: }-43.0 \pm 37.0\end{array}$ & $\begin{array}{l}\text { I: No-P>0.05 } \\
\text { C: No-P>0.05 } \\
\text { Inter-group: No- } P>0.05\end{array}$ \\
\hline & & Get Up and Go (seconds) & $\begin{array}{l}\mathrm{I}:+1.8 \pm 2.8 \\
\mathrm{C}:+2.8 \pm 4.3\end{array}$ & $\begin{array}{l}\text { I: No- }-P>0.05 \\
\text { C: No- } P>0.05 \\
\text { Inter-group: No- } P>0.05\end{array}$ \\
\hline Lombardi et al. [32] & $\begin{array}{l}\text { I: } 13 \\
\text { C: N/A }\end{array}$ & $6 \mathrm{MWT}(\mathrm{m})$ & $\begin{array}{l}\text { I: } 439.1 \pm 64.3 \text { to } 474.2 \pm 89.0 \\
\text { C: N/A }\end{array}$ & $\begin{array}{l}\text { I: Yes-P=0.006 } \\
\text { C: N/A } \\
\text { Inter-group: N/A }\end{array}$ \\
\hline
\end{tabular}

in intervention $(331 \pm 124 \mathrm{~m}$ to $405 \pm 130 \mathrm{~m})$, but not control patients $(298 \pm 142 \mathrm{~m}$ to $310 \pm 155 \mathrm{~m} ; P=0.02)$ [27]. The RCT that did not report control data found an increase in $6 \mathrm{MWT}$ distance, from $366 \pm 110 \mathrm{~m}$ to $410 \pm 107 \mathrm{~m}$ $(P=0.020)$ [28]. In the cohort study, 6MWT distances increased from $439 \pm 64 \mathrm{~m}$ to $474 \pm 89 \mathrm{~m}(P=0.006)$ [32]. The RCT that did not quantitatively report outcome data did not find significant between-group differences in 6MWT distance $(P>0.05)[30]$.

\section{Body mass measurements}

The results for body composition measurements are presented in Table 6 . Three studies involving $n=73$ intervention and $n=49$ control patients reported changes in body mass [27-29]. One study, which prescribed exercise in the intervention and control groups, did not find a significant increase in body mass among intervention patients, when compared to control patients $(P>0.05)$ [29]. One study reported an intra-group body mass increase from $55.9 \pm 17.0 \mathrm{~kg}$ to $58.2 \pm 7.2 \mathrm{~kg}(P<0.010)$ [27], however changes in body mass were not significantly greater than those found in the control group $(P>0.05)$. A third study found an increase in intra-group body mass, from $63.9 \pm 9.4 \mathrm{~kg}$ to $65.5 \pm 10.3 \mathrm{~kg}$ $(P<0.001)$ following the study intervention. However, no control data were reported and inter-group comparisons were not conducted [28].

\section{Body mass index measurements}

Four studies [27, 29, 30] including one cohort study [32] reported data for body mass index [BMI] $(n=77$ intervention and $n=55$ control patients). Only one study reported a significant increase in BMI following supplementation $\left(22.5 \pm 2.1 \mathrm{~kg} / \mathrm{m}^{2}\right.$ to $\left.23.4 \pm 1.9 \mathrm{~kg} / \mathrm{m}^{2} ; P<0.010\right)$ [27]. However, this change was not significantly different to changes reported in the control group.

\section{Fat mass measurements}

Two studies, including $n=37$ intervention and $n=18$ control patients, reported Dual X-ray Absorptiometry (DXA) derived changes in fat mass. One study reported no change in fat mass among intervention group patients, when compared to control group patients $(P>0.05)$ [30]. The second study reported an increase in fat mass, from $15.6 \pm 0.7$ to $16.6 \pm 0.9(P=0.003)$ in the intervention group. No control data were reported and inter-group comparisons were not conducted [28].

\section{Lean mass measurements}

Two studies, including $n=37$ intervention and $n=18$ control patients reported DXA derived changes in lean body mass [30]. Wu and Colleagues [30] reported that lean body mass significantly increased when compared to controls $(P=0.04)$. Rozentryt and colleagues [28] reported that lean body mass increased among intervention patients $(P=0.019)$, but did not report control data.

One study (intervention $\operatorname{arm} n=21$; control arm $n=17$ ) estimated lean body mass using tricep skinfold thickness measurements and arm muscle area $\left(\mathrm{cm}^{2}\right)$ [27]. Tricep skinfold thickness measurements did not change in either study groups ( $P$ value not reported). Arm muscle area increased in 
Table 6 Changes in measurements of body composition (mean \pm SD)

\begin{tabular}{|c|c|c|c|c|}
\hline Study & Sample size $(n=)$ & Measurement of body composition & Change in body composition (SD) & Significant improvement \\
\hline \multirow[t]{4}{*}{ Aquilani et al. [27] } & \multirow[t]{4}{*}{$\begin{array}{l}\mathrm{I}: 21 \\
\mathrm{C}: 17\end{array}$} & $\begin{array}{l}\text { Arm muscle area (Skin fold } \\
\text { measurement-derived; } \mathrm{cm}^{2} \text { ) }\end{array}$ & $\begin{array}{l}\text { I: } 31.2 \pm 9.9 \text { to } 34.9 \pm 10.0 \\
\text { C: } 34.2 \pm 5.0 \text { to } 37.1 \pm 4.0\end{array}$ & $\begin{array}{l}\text { I: Yes }-P<0.020 \\
\text { C: Yes }-P<0.020 \\
\text { Inter-group: } P>0.05\end{array}$ \\
\hline & & Tricep skinfold thickness (mm) & $\begin{array}{l}\text { I: } 10.4 \pm 4.4 \text { to } 10.3 \pm 3.9 \\
\text { C: } 11.9 \pm 3.7 \text { to } 11.4 \pm 3.7\end{array}$ & $\begin{array}{l}\text { I: No- } P>0.05 \\
\text { C: No- } P>0.05 \\
\text { Inter-group: No- } P>0.05\end{array}$ \\
\hline & & Body mass (kg) & $\begin{array}{l}\text { I: } 55.9 \pm 17.0 \text { to } 58.2 \pm 7.2 \\
\text { C: } 60.8 \pm 7.0 \text { to } 61.2 \pm 6.3\end{array}$ & $\begin{array}{l}\text { I: Yes }-P<0.010 \\
\text { C: No- } P>0.05 \\
\text { Inter-group: No-P>0.05 }\end{array}$ \\
\hline & & BMI $\left(\mathrm{kg} / \mathrm{m}^{2}\right)$ & $\begin{array}{l}\text { I: } 22.5 \pm 2.1 \text { to } 23.4 \pm 1.9 \\
\text { C: } 23.2 \pm 1.4 \text { to } 23.6 \pm 1.5\end{array}$ & $\begin{array}{l}\text { I: Yes-P<0.010 } \\
\text { C: No- } P>0.05 \\
\text { Inter-group: No- } P>0.05\end{array}$ \\
\hline \multirow[t]{3}{*}{ Rozentryt et al. [28] } & \multirow[t]{3}{*}{$\begin{array}{l}\text { I: } 23 \\
\text { C: } 6\end{array}$} & Lean body mass (DXA; kg) & $\begin{array}{l}\text { I: } 45.0 \pm 12.5 \text { to } 45.5 \pm 11.2 \\
\text { C: Not reported }\end{array}$ & $\begin{array}{l}\text { I: Yes }-P=0.019 \\
\text { C: No- } P>0.05 \\
\text { Inter-group: Not reported }\end{array}$ \\
\hline & & Fat mass (DXA; kg) & $\begin{array}{l}\text { I: } 15.6 \pm 8.9 \text { to } 16.6 \pm 8.9 \\
\text { C: Not reported }\end{array}$ & $\begin{array}{l}\text { I: Yes-P }-P .003 \\
\text { C: No- } P>0.05 \\
\text { Inter-group: Not reported }\end{array}$ \\
\hline & & Body mass (DXA; kg) & $\begin{array}{l}\text { I: } 63.9 \pm 9.4 \text { to } 65.5 \pm 10.3 \\
\text { C: Not reported }\end{array}$ & $\begin{array}{l}\text { I: Yes-P }-P=0.003 \\
\text { C: No- } P>0.05 \\
\text { Inter-group: Not reported }\end{array}$ \\
\hline \multirow[t]{5}{*}{ Pineda-Juarez et al. [29] } & \multirow[t]{5}{*}{$\begin{array}{l}\text { I: } 29 \\
\text { C: } 26\end{array}$} & Body mass (kg) & $\begin{array}{l}\text { I: }-0.6(-4.4 \text { to } 2.1)^{\mathrm{a}} \\
\mathrm{C}:-0.5(-2.4 \text { to } 2.7)^{\mathrm{a}}\end{array}$ & $\begin{array}{l}\text { I: No-P>0.05 } \\
\text { C: No-P>0.05 } \\
\text { Inter-group: No- } P>0.05\end{array}$ \\
\hline & & $\mathrm{BMI}\left(\mathrm{kg} / \mathrm{m}^{2}\right)$ & $\begin{array}{l}\mathrm{I}:-0.4(-2.7 \text { to } 2.2)^{\mathrm{a}} \\
\mathrm{C}:-0.7(-2.1 \text { to } 2.3)^{\mathrm{a}}\end{array}$ & $\begin{array}{l}\text { I: No- } P>0.05 \\
\text { C: No- } P>0.05 \\
\text { Inter-group: No } P>0.05\end{array}$ \\
\hline & & Arm circumference ( $\%$ change) & $\begin{array}{l}\mathrm{I}:-2.0(-7.4 \text { to } 3.3)^{\mathrm{a}} \\
\mathrm{C}:-4.0(-7.6 \text { to } 0.2)^{\mathrm{a}}\end{array}$ & $\begin{array}{l}\text { I: No- } P>0.05 \\
\text { C: No- } P>0.05 \\
\text { Inter-group: No } P>0.05\end{array}$ \\
\hline & & Hip circumference (\% change) & $\begin{array}{l}\text { I: }-3.1(-6.6 \text { to }-1.1) \\
\text { C: }-1.5(-3.7 \text { to }-1.8)\end{array}$ & $\begin{array}{l}\text { I: No- } P>0.05 \\
\text { C: No- } P>0.05 \\
\text { Inter-group: No } P>0.05\end{array}$ \\
\hline & & Waist circumference ( $\%$ change) & $\begin{array}{l}\mathrm{I}:-0.7(-3.2 \text { to }-3.3) \\
\mathrm{C}:-1.7(-3.7 \text { to }-1.8)\end{array}$ & $\begin{array}{l}\text { I: No- } P>0.05 \\
\text { C: No-P>0.05 } \\
\text { Inter-group: No } P>0.05\end{array}$ \\
\hline \multirow[t]{3}{*}{ Wu et al. [30] } & \multirow[t]{3}{*}{$\begin{array}{l}\text { I: } 14 \\
\text { C: } 12\end{array}$} & Lean body mass (DXA; kg) & $\begin{array}{l}\text { I: } 54.4 \pm 2.8 \text { to } 56.1 \pm 2.5 \\
\text { C: } 52.4 \pm 11.1 \text { to } 53.8 \pm 12.8\end{array}$ & $\begin{array}{l}\text { I: Yes-<0.05 } \\
\text { C: No-P>0.05 } \\
\text { Inter-group: Yes } P=0.040\end{array}$ \\
\hline & & Fat mass (DXA; kg) & $\begin{array}{l}\text { I: } 27.0 \pm 7.5 \text { to } 26.0 \pm 7.5 \\
\text { C: } 25.0 \pm 6.9 \text { to } 26.0 \pm 6.9\end{array}$ & $\begin{array}{l}\text { I: No- } P>0.05 \\
\text { C: No- } P>0.05 \\
\text { Inter-group: No } P>0.05\end{array}$ \\
\hline & & BMI (DXA; kg/m²) & $\begin{array}{l}\text { I: } 30.0 \pm 1.0 \text { to } 30.0 \pm 1.0 \\
\text { C: } 28.0 \pm 2.0 \text { to } 29.0 \pm 2.0\end{array}$ & $\begin{array}{l}\text { I: No }-P>0.05 \\
\text { C: No - } P>0.05 \\
\text { Inter-group: No } P>0.05\end{array}$ \\
\hline Lombardi et al. [32] & $\begin{array}{l}\text { I: } 13 \\
\text { C: N/A }\end{array}$ & $\mathrm{BMI}\left(\mathrm{kg} / \mathrm{m}^{2}\right)$ & $\begin{array}{l}\text { I: } 25.7 \pm 3.2 \text { to } 25.4 \pm 2.8 \\
\text { C: N/A }\end{array}$ & $\begin{array}{l}\text { I: No } \\
\text { C: N/A } \\
\text { Inter-group: N/A }\end{array}$ \\
\hline
\end{tabular}

the intervention and control groups $(P=0.020)$. One study (intervention arm $n=29$; control arm $n=26$; exercise prescribed to both groups) reported arm circumference as an estimate of lean body mass [29]. There was no improvement in arm circumference among intervention group patients, when compared to control group patients $(P>0.05)$.

\section{Aerobic fitness measurements}

Five studies including $n=100$ intervention and $n=61$ control patients assessed changes in aerobic fitness (Table 7) [27-30, 32]. One study did not report control data [28], one was a cohort study [32], and one prescribed exercise to 
Table 7 Changes in measurements of aerobic fitness (mean \pm SD)

\begin{tabular}{|c|c|c|c|c|}
\hline Study & Sample size $(n=)$ & Measurement of aerobic fitness & Change in aerobic fitness (SD) & Significant improvement \\
\hline \multirow[t]{2}{*}{ Aquilani et al [27] } & \multirow[t]{2}{*}{$\begin{array}{l}\text { I: } 21 \\
\text { C: } 17\end{array}$} & $\mathrm{VO}_{2 \text { peak }}(\mathrm{ml} / \mathrm{kg} / \mathrm{min})$ & $\begin{array}{l}\text { I: } 13.5 \pm 1.7 \text { to } 14.9 \pm 1.9 \\
\text { C: } 12.9 \pm 2.7 \text { to } 13.0 \pm 3.5\end{array}$ & $\begin{array}{l}\text { I: Yes }-P<0.050 \\
\text { C: No- } P>0.050 \\
\text { Inter-group: Yes }-P<0.050\end{array}$ \\
\hline & & Peak power output (w) & $\begin{array}{l}\text { I: } 80.0 \pm 28.0 \text { to } 95.0 \pm 25.0 \\
\text { C: } 85.0 \pm 24.0 \text { to } 88.0 \pm 22.0\end{array}$ & $\begin{array}{l}\text { I: Yes }-P<0.020 \\
\text { C: No- } P>0.050 \\
\text { Inter-group: Yes }-P<0.010\end{array}$ \\
\hline Rozentryt et al. [28] & $\begin{array}{l}\text { I: } 23 \\
\text { C: } 6\end{array}$ & $\mathrm{VO}_{2 \text { peak }}(\mathrm{ml} / \mathrm{kg} / \mathrm{min})$ & $\begin{array}{l}\text { I: } 14.5 \pm 2.9 \text { to } 14.9 \pm 3.1 \\
\text { C: Not reported }\end{array}$ & $\begin{array}{l}\text { I: No- } P=0.320 \\
\text { C: No- } P>0.050 \\
\text { Inter-group: Not reported }\end{array}$ \\
\hline Pineda-Juarez et al. [29] & $\begin{array}{l}\mathrm{I}: 29 \\
\mathrm{C}: 26\end{array}$ & Estimated $\mathrm{VO}_{2 \text { peak }}(\%$ change $)$ & $\begin{array}{l}\mathrm{I}:+16.6(0.2 \text { to } 38.5)^{\mathrm{a}} \\
\text { C: } 50.1(-11.2 \text { to } 94.0)^{\mathrm{a}}\end{array}$ & $\begin{array}{l}\mathrm{I}: \mathrm{No}-P>0.05 \\
\mathrm{C}: \mathrm{No}-P>0.05 \\
\text { Inter-group: } \mathrm{No}-P>0.05\end{array}$ \\
\hline Wu et al. [30] & $\begin{array}{l}\text { I: } 14 \\
\text { C: } 12\end{array}$ & $\mathrm{VO}_{2 \text { peak }}(\mathrm{ml} / \mathrm{kg} / \mathrm{min})$ & $\begin{array}{l}\mathrm{I}:+7.9 \pm 17.6 \\
\mathrm{C}:+0.1 \pm 2.6 \%\end{array}$ & $\begin{array}{l}\text { I: No-No- }-P>0.05 \\
\text { C: No- } P>0.05 \\
\text { Inter-group: } \mathrm{No}-P=0.260\end{array}$ \\
\hline \multirow[t]{4}{*}{ Lombardi et al. [32] } & \multirow[t]{4}{*}{$\begin{array}{l}\text { I: } 13 \\
\text { C: N/A }\end{array}$} & $\mathrm{VO}_{2 \text { peak }}(\mathrm{ml} / \mathrm{kg} / \mathrm{min})$ & $\begin{array}{l}\mathrm{I}: 14.8 \pm 3.9 \text { to } 16.8 \pm 5.1 \\
\mathrm{C}: \mathrm{N} / \mathrm{A}\end{array}$ & $\begin{array}{l}\text { I: Yes-P=0.008 } \\
\text { C: N/A } \\
\text { Inter-group: N/A }\end{array}$ \\
\hline & & VAT (ml/kg/min) & $\begin{array}{l}\text { I: } 9.0 \pm 3.8 \text { to } 12.4 \pm 3.9 \\
\text { C:N/A }\end{array}$ & $\begin{array}{l}\text { I: Yes-P=0.002 } \\
\text { C: N/A } \\
\text { Inter-group: N/A }\end{array}$ \\
\hline & & $\mathrm{VE} / \mathrm{VCO}_{2}$ slope & $\begin{array}{l}\text { I: } 37.1 \pm 6.9 \text { to } 37.4 \pm 7.7 \\
\text { C: N/A }\end{array}$ & $\begin{array}{l}\text { I: No - P=0.754 } \\
\text { C: N/A } \\
\text { Inter-group: N/A }\end{array}$ \\
\hline & & Peak power output (w) & I: $100.9 \pm 32.4$ to $104.8 \pm 28.4$ & $\begin{array}{l}\mathrm{I}: \mathrm{No}-P=0.380 \\
\mathrm{C}: \mathrm{N} / \mathrm{A} \\
\text { Inter-group: N/A }\end{array}$ \\
\hline
\end{tabular}

the intervention and control groups [29]. Three studies did not find any changes in either estimated $(P>0.05)$ [29], or directly determined peak oxygen uptake $\left(\mathrm{VO}_{2 \text { peak }}\right)$ following protein and/or EAA supplementation $(P=0.320$ [28] and $P=0.260$ [30]). One study reported a significant increase in $\mathrm{VO}_{2 \text { peak }}(P<0.050)$ and peak power $(P<0.010)$ output among intervention patients, when compared to control patients [27]. The cohort study reported significant improvements in $\mathrm{VO}_{2 \text { peak }}(P=0.008)$ and the ventilatory anaerobic threshold $(P=0.002)$, but not peak power output $(P=0.380)$ or ventilatory efficiency $\left(\mathrm{VE} / \mathrm{VCO}_{2}\right.$ slope; $\left.P=0.754\right)$ [32].

\section{Health related quality of life measurements}

Four studies reported changes in patient HRQoL [28, 30-32]. Three, including one cohort study [32] assessed HRQoL using the Minnesota living with heart failure questionnaire (MLHFQ) [30, 32, 36]. Control data were not reported for either RCT. Two (of three) studies [28, 32] reported an improvement in MLHFQ scores. Rozentryt and colleagues [28] reported a change from $47 \pm 23$ to $37 \pm 27$ $(P<0.001$; control data not reported), whilst $\mathrm{Wu}$ and colleagues [30] reported an improvement from $36 \pm 82$ to $24 \pm 57$ in the intervention, but not control group $(P=0.020$; control data not reported). The same study also assessed changes in HRQoL using the Kansas City Cardiomyopathy Questionnaire (KCCQ) [37]. They identified an overall improvement $(73 \pm 71$ to $83 \pm 45 ; P=0.040)$, improvements in social limitation $(72 \pm 90$ to $86 \pm 56 ; P=0.006)$, and HRQoL ( $62 \pm 101$ to $75 \pm 60 ; P=0.004)$. Lombardi and colleagues [32] did not find an improvement in MLHFQ score $(21 \pm 14$ to $25 \pm 13 ; P=0.321)$.

One study [31], which combined exercise with supplementation in the intervention group only, reported changes in HRQoL using the Short Form Health Survey (SF-36) questionnaire [38]. Only scores for individual questionnaire items were reported. There were no significant changes in SF-36 scores for patients in the intervention $(n=3)$ or control groups $(n=3)$. Cumulative SF-36 scores and SEM values were not reported.

\section{Safety}

Four studies reported serious adverse event and adverse event data (Table 2) [27-30]. There were 21 serious adverse events. Eight of the serious adverse events were deaths [27-29] (4.8\% of study population) [27, 28]. Four of the deaths were among intervention patients, and four among controls. One study involving exercise training for intervention and control patients reported two deaths in each study 
arm, however the cause of death was not reported (total deaths $n=4$ ) [29]. The absolute number of serious adverse events $(n=13)$ was higher among intervention patients compared to controls $(n=8)$. However, due to a higher sample in the intervention compared to control group, the serious adverse event rate was proportionally similar among intervention and control patients, with one serious adverse event for every eight patients recruited. There were a total of 28 adverse events. Adverse events affected one in five patients assigned to intervention groups (total; $n=19$ ), and one in seven patients assigned to control groups (total; $n=9$ ). One study comprehensively reported adverse and serious adverse events [28]. The serious adverse events occurring in this study accounted for $52 \%$ of all serious adverse events $(n=14)$, and $72 \%$ of adverse events $(n=21)$ reported in our systematic review. Renal function was reported using estimated glomerular filtration rate (two studies) [29, 32], serum creatinine levels (four studies) [28-30,32] and serum albumin levels (three studies) [28-30]. No changes in renal function were reported.

\section{Study attrition}

All six studies reported study attrition (Online Resource 5) [27-32]. Study attrition was similar among intervention and control arms. Attrition in the intervention arms ranged from $0 \%$ to $50 \%$, and attrition in the control arms ranged from $0 \%$ to $40 \%$.

\section{Study adherence}

Only one study reported supplementation adherence (Online Resource 5) [27]. Adherence was defined by the total number of empty supplement packets returned by the participant at the end of the intervention. Adherence was further evidenced by blood sample analyses, leucine (EAA) concentrations within the intervention group were $279 \%$ higher than reported at baseline $(P<0.001)$. Based on this, the authors concluded that all participants adhered to the intervention.

\section{Discussion}

\section{Overview}

The primary aim of this systematic review was to assess the effects of dietary protein and/or EAA supplementation on skeletal muscle strength, and performance in patients with CHF. The number of studies $(n=6)$ and total patient population $(n=167)$ were small, and the risk of bias was high in all RCTs. Methods of assessing our outcomes of interest were also heterogeneous, and data were often incompletely reported. For example, in most cases, only two studies reported the same outcome measure, and pooled sample sizes were small. In cases where three or more studies appeared to report the same outcome measure, complete intervention and control outcome data were only reported by two studies. Furthermore, data from the cohort study could not be pooled with data from the RCTs. The heterogeneous nature of these studies meant that meta-analysis was inappropriate [33]. Qualitative data synthesis suggested that dietary supplementation with protein and/or EAA may not improve strength in patients with CHF, [29-31] but may increase muscle performance (6MWT distance) [27, 28, 32]. The secondary findings showed that protein/EAA supplementation may improve lean body mass [28, 30], healthrelated quality of life and appears to be safe. There is limited evidence for the intervention improving aerobic fitness.

\section{Strength measurements}

Recent changes to sarcopenia guidelines advocate primarily identifying low muscle strength [10] instead of lean or fat-free body mass [39] for diagnosis. Developing an intervention that can increase strength and avoid or defer the development of sarcopenia in patients with $\mathrm{CHF}$ is required. We identified three studies that measured changes in muscle strength, none of which reported a significant improvement following protein and/or EAA supplementation despite two of the studies employing a combined resistance exercise and protein/EAA intervention. Similar findings have previously been reported in non-frail elderly individuals [40], however evidence appears to support the beneficial role of protein and/or EAA supplementation in increasing strength in healthy adults [16] and undernourished people with a long-term condition [17].

A review of 49 studies by Morton and colleagues [16] reported a mean 1 repetition maximum (1RM) strength increase of $27.0 \mathrm{~kg}$ (95\% CI 22.0-32.0 kg) following combined resistance exercise training and protein supplementation in healthy adults. Dietary protein supplementation resulted in a further modest 1RM increase of $2.5 \mathrm{~kg}$ (95\% CI $0.6-4.3 \mathrm{~kg}$ ), indicating that protein supplementation plays a smaller role in improving strength, in comparison to resistance exercise training. Similarly, a systematic review by Cheng and colleagues [17] found that dietary protein and/or amino acid supplementation elicited modest improvements in strength in people with a long-term condition (standardised mean difference [SMD]: $0.27 \mathrm{~kg}$; $95 \%$ CI $0.1-0.4 \mathrm{~kg}$; $P<0.01)$ [17]. These findings appeared more pronounced in individuals who were undernourished. Interestingly, only one study identified by Cheng and colleagues [27] specifically recruited patients with CHF. Our findings confirm that there is a paucity of data in this population that has a high incidence of sarcopenia. 
Similar to our review, the review by Cheng and colleagues [17] extracted data from a study by Aquilani and colleagues [27]. Details of this intervention are reported in Table 2. Aquilani and colleagues measured aerobic fitness on a cycle ergometer. However, this was interpreted to be a measure of strength by Cheng and colleagues. Peak aerobic fitness is determined by oxygen transport to the muscle and muscle oxygen extraction [41] and may not reflect changes in muscular strength. Despite this important discrepancy, the findings of systematic reviews on protein and/or EAA supplementation in older adults with [17] or without [40] longterm conditions lend support to our observation that protein and/or EAA supplementation either does not improve or has a small effect on improving muscular strength [17, 40]. This may be because muscular strength is dependent on neurological activation of the muscle, as well as increases in lean muscle mass [42]. Protein and/or EAA supplementation alone may not stimulate improvements in motor unit recruitment required for strength development. Mechanical stimuli, such as that provided by resistance exercise training, may be required to optimise the potential benefits that supplementation may provide.

We identified two studies that measured changes in strength following protein and/or EAA supplementation and exercise training. However, the study design limited the ability to adequately evaluate whether this combined approach is effective in improving strength. George et al. [31] assessed the feasibility of protein supplementation and exercise training in patients with CHF [31]. No significant improvements in strength were reported, however, the study was not powered to detect statistically significant changes in physiological outcomes ( $n=3$ per study group) [31]. Pineda-Juarez and colleagues [29] also reported no improvement in strength among patients who were randomised to EAA supplementation or control groups. However, this study was limited by patients having an average energy intake of $\sim 1423 \mathrm{kcal}$ per day; a substantially lower dietary energy intake than is currently recommended for adult males and females $(\sim 2000$ to $\sim 2500 \mathrm{kcal}$ ) [43]. Low dietary energy intake combined with increased energy expenditure with resistance exercise training may have exacerbated the catabolic nature of CHF [44]. Furthermore, Pineda-Juarez et al. [29] removed $10 \mathrm{~g}$ of protein from intervention patients' diets, before providing the twice daily $5 \mathrm{~g}$ non-EAA and EAA mixture. Each $5 \mathrm{~g}$ supplement, however, only contained $3.75 \mathrm{~g}$ of non-EAA and EAA's. Compared to baseline, patients in the intervention group therefore consumed 2.5 fewer grams of protein per day than the control group, for the duration of the study [29]. Collectively, these factors may limit any expected improvements in strength, among patients assigned to the intervention group. Protein/EAA supplementation does not appear to improve strength of patients with CHF.

\section{Body mass measurements}

Three of five studies that measured body mass, reported an increase in at least one surrogate marker of lean muscle mass (arm muscle area, arm circumference and, BMI) [27, 28, 30]. Two studies also reported an increase in DXA-derived measurements of lean body mass [28, 30], the reference standard for measuring body mass in sarcopenia [45]. Similar to data reported in healthy older people [16] and people living with a long-term condition [17], protein and/or EAA supplementation in patients with CHF led to an increase in lean body mass (DXA: $0.5-1.7 \mathrm{~kg}$ ) $[28,30]$. Protein/EAA supplementation appears to be beneficial in improving lean mass.

Despite increases in lean mass, $\mathrm{Wu}$ and colleagues [30] did not report any changes in fat mass, BMI or lipid profiles, suggesting that cardiometabolic health was maintained throughout the supplementation period. This study increased dietary energy intake by $90 \mathrm{kcal}$ per day. However, Rozentryt and colleagues [28] reported that a $300 \mathrm{kcal}$ twice daily multi-macronutrient supplementation $(20 \mathrm{~g}$ of protein, $72 \mathrm{~g}$ carbohydrate and $26 \mathrm{~g}$ of fat) led to an increase in total body mass and fat mass [28]. Given that $600 \mathrm{kcal} /$ day constitutes approximately $35-45 \%$ of the daily energy expenditure of CHF patients [46], it is unsurprising that such an increase in dietary intake for 3 months led to increases in lean mass and fat mass.

Previous evidence suggests that mortality risk [47] and cardiac stress markers (NT-proBNP) [48] are lower in CHF patients who are overweight (BMI of up to $29 \mathrm{~kg} / \mathrm{m}^{2}$ ). Therefore, one might assume that the increases in body mass reported by Rozentryt and colleagues [25] are beneficial. However, high fat mass could be detrimental in CHF due to the observed higher level of inflammation (high-sensitivity C-reactive protein) and lower 6MWT distances [48]. High levels of inflammation may increase the risk of developing sarcopenia, and is associated with the progression of CHF $[10,49,50]$. Furthermore, greater six-minute walk test distances confer superior survival outcomes [51] and better HRQoL in patients with CHF [52]. Increasing body mass, without increasing fat mass may help to preserve 6MWT distance and consequently, HRQoL in people with CHF. Improved lean and total body masses without increased fat mass may be achieved with small increases in caloric intake (90 kcal) by predominantly supplementing with pro-anabolic EAA and non-EAAs [30].

\section{Muscle performance}

Three of the four studies that measured 6MWT distance reported a significant improvement among intervention patients, but not controls. The only study that did not report a significant improvement was a feasibility study with low 
statistical power ( $n=3$ per group) [31]. Change in 6MWT distance exceeded the widely accepted minimally important improvement for people with CHF (43 m) [53] in two studies $[27,28]$. These improvements are consistent with the effects of protein and/or EAA supplementation in people with a long-term condition [17] and similar to improvements reported after exercise-based cardiac rehabilitation in patients with CHF (46 m; $P<0.001)$ [54].

It is noteworthy that the gold standard measurement of aerobic fitness, $\mathrm{VO}_{2 \text { peak }}$, increased in only two out of five studies [27, 32]. This may suggest that protein and/or EAA supplementation is more likely to improve sub-maximal muscle performance, rather than maximal aerobic fitness. Protein and EAA supplementation appears to improve muscle performance assessed by walking distance.

\section{Health-related quality of life measurements}

Changes in HRQoL were typically reported using the MLHFQ [28, 30] and the KCCQ [30]. The MLHFQ and KCCQ require patients to provide responses to questions relating to the impact that CHF has on their physical, emotional and socio-economic function. They are widely adopted in clinical trials involving patients with $\mathrm{CHF}$ and are likely to be sensitive to changes in frailty. However, to our knowledge, their sensitivity to changes in strength, muscle mass or performance has not been investigated. Therefore, it is possible that changes in HRQoL may not have been adequately captured. It is noteworthy that none of the studies in our systematic review used qualitative methods to explore changes in HRQoL. Qualitative research methods can provide important context to HRQoL data obtained from questionnaires and can help researchers to interpret quantitative findings [55]. Qualitative research methods, such as patient interviews, could help to further our understanding of the impact the protein and/or EAA supplementation has on HRQoL. Based on the available evidence, protein and/ or EAA supplementation may lead to an improvement in HRQoL.

\section{Attrition}

In a RCT, high levels of patient attrition can increase the likelihood of a biased outcome and misleading findings [56]. Five out of six studies in our systematic review had an attrition rate $<20 \%$ [27-30, 32]. Attrition rates between 5\% and $20 \%$ are likely to lead to a modest risk of outcome bias in RCTs [57]. The observed low to modest risk of bias suggests that adequately powered RCTs, investigating protein and/or EAA supplementation, may be feasible.

\section{Adherence}

Recording adherence to nutritional supplementation in home-based interventions can be difficult. Only one study reported intervention adherence in our systematic review [27]. Adherence was estimated by counting the number of empty supplement packets those were returned to the research team and the increases in plasma EAA concentractions. It is promising that Aquilani and colleagues [27] found that $100 \%$ of patients adhered to their intervention. However, detailed information on adherence to protein and/or EAA supplementation in patients with CHF is required to determine whether patients are likely to adhere to protein and/or EAA supplementation in clinical practice.

\section{Safety}

Diets that are high in protein have been associated with a decline in renal function over a 41-month period, in patients with heart disease [24]. Therefore, the benefits of treating sarcopenia in patients with CHF using protein and/or EAA supplementation need to be evaluated against the risk of a decline in renal function. The data available in our systematic review suggest that interventions using protein and/or EAA supplementation that last up to 3 months [28, 30, 32] may not have a negative effect on renal function. However, this finding should be interpreted with caution, because adverse event reporting was often incomplete. Available adverse event data indicate that a proportionately similar number of adverse events were experienced by patients in intervention and control arms, and no significant safety concerns have been identified in our systematic review. However, it is essential that future clinical trials in this field of research report adverse events in a transparent way [22].

\section{Limitations}

The paucity of studies that supplemented CHF patients with protein and/or EAA with the aim of improving muscular strength or performance limited the strength of our findings. Furthermore, the risk of bias was high, outcome measures were heterogeneous and the quality of data reporting was varied, and often incomplete. This precluded metaanalysis, and therefore estimation of the intervention effect size. The conclusions that can be drawn from our findings are therefore limited. Qualitative interpretation of the studies included in our review also indicated that a number of studies had design limitations. These may have influenced the outcomes of the studies and consequently our systematic review. One important design limitation was that only two studies prescribed and recorded exercise participation during the study. Exercise is a potent stimulator of muscle anabolism and strength, and patients with $\mathrm{CHF}$ are advised to 
participate in structured exercise training, however, participation is highly variable. Not recording or controlling patient participation in structured exercise training may attenuate the overall effect signal for the protein/EAA intervention.

\section{Future studies}

It is clear from the small number of studies included in this review, and their recent publication dates, that this field of research is in its infancy. Future research should take into consideration the high risk of bias and low quality of the study methods observed in the studies included in this review. To improve the quality of future research, transparent reporting of adverse events, reporting changes in renal function, adherence to supplementation regimens, and qualitatively exploring patient experiences of participating in a protein and/or EAA supplementation regimen should be considered as priorities for future studies. Further qualitative research is needed to increase our understanding of how protein and/or EAA supplementation may improve HRQoL in patients with CHF. This may be achieved, in part, by validation of the MLHFQ and KCCQ questionnaires against measurements of sarcopenia. Alternatively, validating sarcopenia specific questionnaires such as the recently developed SarQoL [58] in patients with CHF may provide additional information on changes in HRQoL following protein and/or EAA supplementation. Researchers should also consider whether using protein and/or EAA supplementation results in a significant increase in daily calorie intake, and what effect this may have on markers of cardiometabolic health, inflammation and muscle performance. Finally, further research is needed to explore whether exercise training may augment any benefits associated with protein and/ or EAA supplementation for the treatment of sarcopenia in patients with CHF.

\section{Conclusions}

Protein and/or EAA supplementation appears to be safe, may increase lean body mass and 6MWT distance, but not strength in patients with CHF. Trials reporting changes in strength had substantial limitations and these findings should be interpreted with caution. Combining strength training with protein supplementation optimises muscle strength and performance adaptations in healthy older participants. Research investigating the benefits of protein and/or EAA supplementation combined with resistance exercise training in patients with CHF is needed.

Acknowledgements The authors would like to thank Matthew Cooper at The University of Sheffield for his assistance in constructing our search strategy.

Funding No funding was received to undertake this systematic review.

\section{Compliance with ethical standards}

Conflict of interest The authors declare no conflict of interest.

Ethical approval The manuscript does not contain clinical studies or patient data.

Open Access This article is distributed under the terms of the Creative Commons Attribution 4.0 International License (http://creativeco mmons.org/licenses/by/4.0/), which permits unrestricted use, distribution, and reproduction in any medium, provided you give appropriate credit to the original author(s) and the source, provide a link to the Creative Commons license, and indicate if changes were made.

\section{References}

1. van Riet EES, Hoes AW, Wagenaar KP, Limburg A, Landman MAJ, Rutten FH (2016) Epidemiology of heart failure: the prevalence of heart failure and ventricular dysfunction in older adults over time. A systematic review. Eur J Heart Fail 18(3):242-252. https://doi.org/10.1002/ejhf.483

2. Schocken DD, Benjamin EJ, Fonarow GC, Krumholz HM, Levy D, Mensah GA, Narula J, Shor ES, Young JB, Hong Y (2008) Prevention of heart failure: a scientific statement from the American Heart Association Councils on Epidemiology and Prevention, clinical cardiology, cardiovascular nursing, and high blood pressure research; Quality of Care and Outcomes Research Interdisciplinary Working Group; and Functional Genomics and Translational Biology Interdisciplinary Working Group. Circulation 117(19):2544-2565. https://doi.org/10.1161/circulatio naha.107.188965

3. Hirai DM, Musch TI, Poole DC (2015) Exercise training in chronic heart failure: improving skeletal muscle $\mathrm{O}_{2}$ transport and utilization. Am J Physiol Heart Circ Physiol 309(9):H1419H1439. https://doi.org/10.1152/ajpheart.00469.2015

4. Poole DC, Hirai DM, Copp SW, Musch TI (2012) Muscle oxygen transport and utilization in heart failure: implications for exercise (in) tolerance. Am J Physiol Heart Circ Physiol 302(5):H1050-H1063

5. Clark AL, Poole-Wilson PA, Coats AJS (1996) Exercise limitation in chronic heart failure: central role of the periphery. J Am Coll Cardiol 28(5):1092-1102. https://doi.org/10.1016/S0735 -1097(96)00323-3

6. Haykowsky MJ, Tomczak CR, Scott JM, Paterson DI, Kitzman DW (2015) Determinants of exercise intolerance in patients with heart failure and reduced or preserved ejection fraction. J Appl Physiol 119(6):739-744. https://doi.org/10.1152/japplphysi ol.00049.2015

7. Sarma S, Levine BD (2015) Soothing the sleeping giant: improving skeletal muscle oxygen kinetics and exercise intolerance in HFpEF. J Appl Physiol 119(6):734-738. https://doi.org/10.1152/ japplphysiol.01127.2014

8. Shelton RJ, Ingle L, Rigby AS, Witte KK, Cleland JG, Clark AL (2010) Cardiac output does not limit submaximal exercise capacity in patients with chronic heart failure. Eur J Heart Fail 12(9):983-989

9. von Haehling S, Ebner N, dos Santos MR, Springer J, Anker SD (2017) Muscle wasting and cachexia in heart failure: mechanisms and therapies. Nat Rev Cardiol 14:323. https://doi.org/10.1038/ nrcardio.2017.51

10. Cruz-Jentoft AJ, Bahat G, Bauer J, Boirie Y, Bruyere O, Cederholm T, Cooper C, Landi F, Rolland Y, Sayer AA, Schneider SM, Sieber CC, Topinkova E, Vandewoude M, Visser M, Zamboni M 
(2018) Sarcopenia: revised European consensus on definition and diagnosis. Age Ageing. https://doi.org/10.1093/ageing/afy 169

11. Fülster S, Tacke M, Sandek A, Ebner N, Tschöpe C, Doehner W, Anker SD, Von Haehling S (2013) Muscle wasting in patients with chronic heart failure: results from the studies investigating co-morbidities aggravating heart failure (SICA-HF). Eur Heart J 34(7):512-519

12. Cicoira M, Zanolla L, Franceschini L, Rossi A, Golia G, Zamboni M, Tosoni P, Zardini P (2001) Skeletal muscle mass independently predicts peak oxygen consumption and ventilatory response during exercise in noncachectic patients with chronic heart failure. J Am Coll Cardiol 37(8):2080-2085. https://doi.org/10.1016/ S0735-1097(01)01306-7

13. Yamada S, Kamiya K, Kono Y (2015) Frailty may be a risk marker for adverse outcome in patients with congestive heart failure. ESC Heart Fail 2(3):168-170. https://doi.org/10.1002/ehf2.12052

14. Bekfani T, Pellicori P, Morris DA, Ebner N, Valentova M, Steinbeck L, Wachter R, Elsner S, Sliziuk V, Schefold JC, Sandek A, Doehner W, Cleland JG, Lainscak M, Anker SD, von Haehling S (2016) Sarcopenia in patients with heart failure with preserved ejection fraction: impact on muscle strength, exercise capacity and quality of life. Int J Cardiol 222:41-46. https://doi.org/10.1016/j. ijcard.2016.07.135

15. Harada H, Kai H, Niiyama H, Nishiyama Y, Katoh A, Yoshida N, Fukumoto Y, Ikeda H (2017) Effectiveness of cardiac rehabilitation for prevention and treatment of sarcopenia in patients with cardiovascular disease: a retrospective cross-sectional analysis. J Nutr Health Aging 21(4):449-456. https://doi.org/10.1007/s1260 3-016-0743-9

16. Morton RW, Murphy KT, McKellar SR, Schoenfeld BJ, Henselmans M, Helms E, Aragon AA, Devries MC, Banfield L, Krieger JW, Phillips SM (2017) A systematic review, meta-analysis and meta-regression of the effect of protein supplementation on resistance training-induced gains in muscle mass and strength in healthy adults. Br J Sports Med. https://doi.org/10.1136/bjspo rts-2017-097608

17. Cheng H, Kong J, Underwood C, Petocz P, Hirani V, Dawson B, O'Leary F (2018) Systematic review and meta-analysis of the effect of protein and amino acid supplements in older adults with acute or chronic conditions. Br J Nutr 119(5):527-542. https://doi. org/10.1017/S0007114517003816

18. Katsanos CS, Kobayashi H, Sheffield-Moore M, Aarsland A, Wolfe RR (2006) A high proportion of leucine is required for optimal stimulation of the rate of muscle protein synthesis by essential amino acids in the elderly. Am J Physiol Endocrinol Metab 291(2):E381-E387. https://doi.org/10.1152/ajpendo.00488 .2005

19. Rennie MJ, Edwards RH, Halliday D, Matthews DE, Wolman SL, Millward DJ (1982) Muscle protein synthesis measured by stable isotope techniques in man: the effects of feeding and fasting. Clin Sci (Lond, Engl) 63(6):519-523

20. Landi F, Calvani R, Tosato M, Martone AM, Ortolani E, Savera G, D'Angelo E, Sisto A, Marzetti E (2016) Protein intake and muscle health in old age: from biological plausibility to clinical evidence. Nutrients. https://doi.org/10.3390/nu8050295

21. Moher D, Liberati A, Tetzlaff J, Altman DG (2009) Preferred reporting items for systematic reviews and meta-analyses: the PRISMA statement. PLoS Med 6(7):e1000097

22. Ioannidis JP, Evans SJ, Gotzsche PC, O’Neill RT, Altman DG, Schulz K, Moher D (2004) Better reporting of harms in randomized trials: an extension of the CONSORT statement. Ann Intern Med 141(10):781-788. https://doi.org/10.7326/0003-4819141-10-200411160-00009

23. Government B (2004) The Medicines for Human Use (Clinical Trials) Regulations 2004. http://www.legislation.gov.uk/ uksi/2004/1031/pdfs/uksi_20041031_en.pdf
24. Esmeijer K, Geleijnse JM, de Fijter JW, Kromhout D, Hoogeveen EK (2019) Dietary protein intake and kidney function decline after myocardial infarction: the alpha omega cohort. Nephrol Dial Transpl. https://doi.org/10.1093/ndt/gfz015

25. Higgins JPT, Altman DG, Gøtzsche PC, Jüni P, Moher D, Oxman AD, Savović J, Schulz KF, Weeks L, Sterne JAC (2011) The Cochrane collaboration's tool for assessing risk of bias in randomised trials. BMJ 343:d5928

26. Pace R, Pluye P, Bartlett G, Macaulay AC, Salsberg J, Jagosh J, Seller R (2012) Testing the reliability and efficiency of the pilot mixed methods appraisal tool (MMAT) for systematic mixed studies review. Int J Nurs Stud 49(1):47-53. https://doi.org/10.1016/j. ijnurstu.2011.07.002

27. Aquilani R, Opasich C, Gualco A, Verri M, Testa A, Pasini E, Viglio S, Iadarola P, Pastoris O, Dossena M, Boschi F (2008) Adequate energy-protein intake is not enough to improve nutritional and metabolic status in muscle-depleted patients with chronic heart failure. Eur J Heart Fail 10(11):1127-1135. https:// doi.org/10.1016/j.ejheart.2008.09.002

28. Rozentryt P, von Haehling S, Lainscak M, Nowak JU, KalantarZadeh K, Polonski L, Anker SD (2010) The effects of a highcaloric protein-rich oral nutritional supplement in patients with chronic heart failure and cachexia on quality of life, body composition, and inflammation markers: a randomized, double-blind pilot study. J Cachexia Sarcopenia Muscle 1(1):35-42. https://doi. org/10.1007/s13539-010-0008-0

29. Pineda-Juarez JA, Sanchez-Ortiz NA, Castillo-Martinez L, OreaTejeda A, Cervantes-Gaytan R, Keirns-Davis C, Perez-Ocampo C, Quiroz-Bautista K, Tenorio-Dupont M, Ronquillo-Martinez A (2016) Changes in body composition in heart failure patients after a resistance exercise program and branched chain amino acid supplementation. Clinical Nutr (Edinb, Scotl) 35(1):41-47. https ://doi.org/10.1016/j.clnu.2015.02.004

30. Wu C, Kato TS, Ji R, Zizola C, Brunjes DL, Deng Y, Akashi H, Armstrong HF, Kennel PJ, Thomas T, Forman DE, Hall J, Chokshi A, Bartels MN, Mancini D, Seres D, Schulze PC (2015) Supplementation of L-alanyl-L-glutamine and fish oil improves body composition and quality of life in patients with chronic heart failure. Circ Heart Fail 8(6):1077-1087. https://doi.org/10.1161/ circheartfailure.115.002073

31. George M, Azhar G, Pangle A, Peeler E, Dawson A, Coker R, Coleman KS, Schrader A, Wei J (2017) Feasibility of conducting a 6-month long home-based exercise program with protein supplementation in elderly community-dwelling individuals with heart failure. J Physiother Phys Rehabilit. https://doi.org/10.4172/25730312.1000137

32. Lombardi C, Carubelli V, Lazzarini V, Vizzardi E, Quinzani F, Guidetti F, Rovetta R, Nodari S, Gheorghiade M, Metra M (2014) Effects of oral amino acid supplements on functional capacity in patients with chronic heart failure. Clin Med Insights Cardiol 8:39-44. https://doi.org/10.4137/cmc.s14016

33. Ryan R, Cochrane Consumers and Communication Review Group (2016) Heterogeneity and subgroup analyses in Cochrane Consumers and Communication Group reviews: planning the analysis at protocol stage. http://cccrg.cochrane.org

34. McMurray JJV, Adamopoulos S, Anker SD, Auricchio A, Böhm M, Dickstein K, Falk V, Filippatos G, Fonseca C, Gomez-Sanchez MA, Jaarsma T, Køber L, Lip GYH, Maggioni AP, Parkhomenko A, Pieske BM, Popescu BA, Rønnevik PK, Rutten FH, Schwitter J, Seferovic P, Stepinska J, Trindade PT, Voors AA, Zannad F, Zeiher A (2012) ESC Guidelines for the diagnosis and treatment of acute and chronic heart failure 2012: the task force for the diagnosis and treatment of acute and chronic heart failure 2012 of the European society of cardiology. Developed in collaboration with the Heart Failure Association (HFA) of the ESC. Eur Heart J 33(14):1787-1847. https://doi.org/10.1093/eurheartj/ehs104 
35. Frisancho AR (1981) New norms of upper limb fat and muscle areas for assessment of nutritional status. Am J Clin Nutr 34(11):2540-2545. https://doi.org/10.1093/ajcn/34.11.2540

36. Rector T (1987) Patient's self-assessment of their congestive heart failure: II. Content, reli-ability and validity of a new measure-the minnesota living with heart failure questionnaire. Heart Fail 3:198

37. Green CP, Porter CB, Bresnahan DR, Spertus JA (2000) Development and evaluation of the Kansas city cardiomyopathy questionnaire: a new health status measure for heart failure. J Am Coll Cardiol 35(5):1245-1255. https://doi.org/10.1016/s0735 -1097(00)00531-3

38. Ware JE Jr, Sherbourne CD (1992) The MOS 36-item short-form health survey (SF-36) I. Conceptual framework and item selection. Med Care 30(6):473-483

39. Cruz-Jentoft AJ, Baeyens JP, Bauer JM, Boirie Y, Cederholm T, Landi F, Martin FC, Michel J-P, Rolland Y, Schneider SM (2010) Sarcopenia: European consensus on definition and diagnosis Report of the European Working Group on Sarcopenia in Older People. Age Ageing 39(4):412-423

40. ten Haaf DSM, Nuijten MAH, Maessen MFH, Eijsvogels TMH, Hopman MTE, Horstman AMH (2018) Effects of protein supplementation on lean body mass, muscle strength, and physical performance in nonfrail community-dwelling older adults: a systematic review and meta-analysis. Am J Clin Nutr 108(5):1043-1059. https://doi.org/10.1093/ajcn/nqy192

41. Nichols S, Taylor C, Ingle L (2015) A clinician's guide to cardiopulmonary exercise testing 2: test interpretation. Br J Hosp Med 76(5):281-289. https://doi.org/10.12968/hmed.2015.76.5.281

42. Faulkner JA, Larkin LM, Claflin DR, Brooks SV (2007) Agerelated changes in the structure and function of skeletal muscles. Clin Exp Pharmacol Physiol 34(11):1091-1096. https://doi.org/1 0.1111/j.1440-1681.2007.04752.x

43. Johnson RK, Appel LJ, Brands M, Howard BV, Lefevre M, Lustig RH, Sacks F, Steffen LM, Wylie-Rosett J (2009) Dietary sugars intake and cardiovascular health: a scientific statement from the American Heart Association. Circulation 120(11):1011-1020

44. Witte KK, Clark AL, Cleland JG (2001) Chronic heart failure and micronutrients. J Am Coll Cardiol 37(7):1765-1774

45. Buckinx F, Landi F, Cesari M, Fielding RA, Visser M, Engelke K, Maggi S, Dennison E, Al-Daghri NM, Allepaerts S, Bauer J, Bautmans I, Brandi ML, Bruyère O, Cederholm T, Cerreta F, Cherubini A, Cooper C, Cruz-Jentoft A, McCloskey E, DawsonHughes B, Kaufman J-M, Laslop A, Petermans J, Reginster J-Y, Rizzoli R, Robinson S, Rolland Y, Rueda R, Vellas B, Kanis JA (2018) Pitfalls in the measurement of muscle mass: a need for a reference standard. J Cachexia Sarcopenia Muscle 9(2):269-278. https://doi.org/10.1002/jcsm.12268

46. Toth MJ, Gottlieb SS, Goran MI, Fisher ML, Poehlman ET (1997) Daily energy expenditure in free-living heart failure patients. Am J Physiol 272(3 Pt 1):E469-E475. https://doi.org/10.1152/ajpen do.1997.272.3.E469
47. Güder G, Frantz S, Bauersachs J, Allolio B, Wanner C, Koller Michael T, Ertl G, Angermann CE, Störk S (2009) Reverse epidemiology in systolic and nonsystolic heart failure. Circ Heart Fail 2(6):563-571. https://doi.org/10.1161/CIRCHEARTFAILUR E.108.825059

48. Oreopoulos A, Ezekowitz JA, McAlister FA, Kalantar-Zadeh K, Fonarow GC, Norris CM, Johnson JA, Padwal RS (2010) Association between direct measures of body composition and prognostic factors in chronic heart failure. Mayo Clin Proc 85(7):609-617. https://doi.org/10.4065/mcp.2010.0103

49. Kalantar-Zadeh K, Anker SD, Horwich TB, Fonarow GC (2008) Nutritional and anti-inflammatory interventions in chronic heart failure. Am J Cardiol 101(11a):89e-103e. https://doi. org/10.1016/j.amjcard.2008.03.007

50. Yndestad A, Damås JK, Øie E, Ueland T, Gullestad L, Aukrust P (2007) Role of inflammation in the progression of heart failure. Curr Cardiol Rep 9(3):236-241. https://doi.org/10.1007/BF029 38356

51. Forman DE, Fleg JL, Kitzman DW, Brawner CA, Swank AM, McKelvie RS, Clare RM, Ellis SJ, Dunlap ME, Bittner V (2012) 6-min walk test provides prognostic utility comparable to cardiopulmonary exercise testing in ambulatory outpatients with systolic heart failure. J Am Coll Cardiol 60(25):2653-2661. https://doi. org/10.1016/j.jacc.2012.08.1010

52. Westlake C, Dracup K, Creaser J, Livingston N, Heywood JT, Huiskes BL, Fonarow G, Hamilton M (2002) Correlates of healthrelated quality of life in patients with heart failure. Heart Lung 31(2):85-93. https://doi.org/10.1067/mhl.2002.122839

53. American Thoracic Society (2002) ATS statement: guidelines for the six-minute walk test. Am J Respir Crit Care Med 166(1):111

54. van Tol BAF, Huijsmans RJ, Kroon DW, Schothorst M, Kwakkel G (2006) Effects of exercise training on cardiac performance, exercise capacity and quality of life in patients with heart failure: a meta-analysis. Eur J Heart Fail 8(8):841-850. https://doi. org/10.1016/j.ejheart.2006.02.013

55. Ritchie J, Spencer L (2002) Qualitative data analysis for applied policy research. The qualitative researcher's companion, vol 573. Routledge, London, pp 305-329

56. Dumville JC, Torgerson DJ, Hewitt CE (2006) Reporting attrition in randomised controlled trials. BMJ 332(7547):969-971. https:// doi.org/10.1136/bmj.332.7547.969 (Clinical research ed)

57. Schulz KF, Grimes DA (2002) Sample size slippages in randomised trials: exclusions and the lost and wayward. Lancet (Lond, Engl) 359(9308):781-785. https://doi.org/10.1016/s0140 -6736(02)07882-0

58. Beaudart C, Biver E, Reginster JY, Rizzoli R, Rolland Y, Bautmans I, Petermans J, Gillain S, Buckinx F, Dardenne N, Bruyere O (2017) Validation of the SarQoL(R), a specific health-related quality of life questionnaire for Sarcopenia. J Cachexia Sarcopenia Muscle 8(2):238-244. https://doi.org/10.1002/jcsm.12149 